KNOWLEDGE IS THE KEY TO RICHES. IS THE LAW (OR ANYTHING ELSE) PROTECTING IT ADEQUATELY?

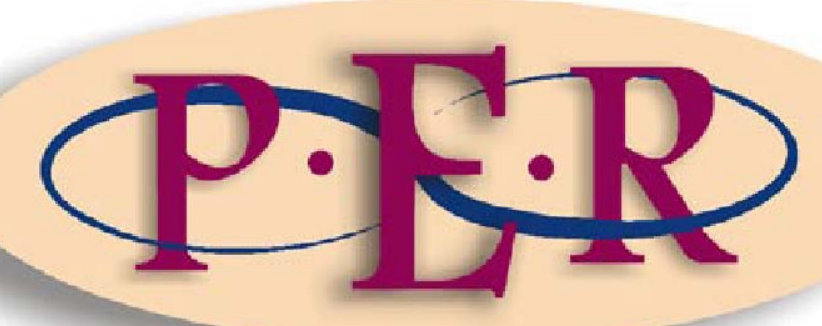

2008 VOLUME 11 NO 4 


\section{KNOWLEDGE IS THE KEY TO RICHES. IS THE LAW (OR ANYTHING ELSE) PROTECTING IT ADEQUATELY?}

\section{D van der Merwe*}

\section{"Knowledge is power" (Sir Francis Bacon)}

\section{Introduction}

In my own humble opinion, the life of Sir Francis Bacon was a good illustration of the abstract theories he espoused. Not only did he invent the scientific method of empiric investigation, but he is also well-known for informed works of science fiction such as Atlantis. Some people ${ }^{1}$ are of the opinion that only a man of his erudite learning possessed the skill and talent to author works of genius such as the plays of "Shakespeare", the latter being a character whose curriculum vitae does not quite measure up to these standards.

Whatever the pros and cons of his other utterances, there is little doubt of the prophetic wisdom of Bacon's statement as quoted at the beginning of this article, particularly at the beginning of the $21^{\text {st }}$ Century. Amongst all his other talents, Bacon was a lawyer too and he should, perhaps, have warned us of the law's lack of capacity ${ }^{2}$ to protect data, information, knowledge or even wisdom. At the risk of over-simplifying matters, this is probably as a result of the development of technology's outpacing legal development by a considerable distance.

In a previous article ${ }^{3}$ endeavoured to explain how the invention of certain Industrial Age technologies, such as the printing press (by Gutenberg) and

* Dana van der Merwe is Professor in Law at the University of South Africa (UNISA).

1 Amongst whom may be counted the present author.

2 Even at the beginning of the $21^{\text {st }}$ Century.

3 Van der Merwe 1998 SALJ $180 \mathrm{ff}$. 
movable type (by Caxton), forced the legal system to conceptualise and invent a whole new branch of the law, namely that of Intellectual Property (IP) law. IP law has coped reasonably well with that generation of technologies, but has proved to be less adept in dealing with the very latest technology wave, variously termed 'computer law', 'Information Technology' (IT) and 'Information and Communication Technology' (ICT) law, amongst other similar phrases. These developments have been lumped together descriptively in the term 'The Third Wave', ${ }^{4}$ as representing a qualitatively new wave of development.

\section{The Information Revolution (The Third Wave)}

The phrase, the 'Third Wave', originated with futurologist Alvin Toffler, author of the work by the same name. ${ }^{5}$ Toffler distinguishes between three so-called 'waves' of technological development. ${ }^{6}$

The first wave of development took place when kings started rewarding the loyalty of their subjects by giving pieces of land to them. Often a recipient of the king's favour in this kind became known by his piece of land, as, for instance 'the Duke of Norfolk', 'the Earl of Surrey' or even, in the case of the king's heir apparent, 'the Prince of Wales'. In South Africa, the Voortrekker ${ }^{7}$ leader Piet Retief tried to earn a grant of land from the King of the Zulus by reclaiming some cattle from another chief. That deal, unfortunately, did not work out and ended with extreme prejudice to one of the parties.

The second wave of development took place in the so-called 'modern' era, perhaps better known as the "age of industrialisation". Because farmers started replacing their manual labourers with farming machinery those, labourers had to move to the cities to help to operate larger and more sophisticated pieces of

$4 \quad$ This term is fully explained under the following heading.

Toffler The Third Wave.

See Van der Merwe, supra n 3, 199-200.

A group of white settlers moving into the interior of South Africa to farm. 
industrial machinery. ${ }^{8}$ A characteristic of the industrial revolution was, of course, when people started organising themselves into organised labour movements, to help prevent exploitation by the capitalists. The ultimate Utopia of this movement was perhaps Mao Tse Toung's vision of "an iron-smelting oven in every back yard". This would simply have caused a lot of pollution and it is only now, having fully embraced the third wave of development, that former 'Third World' countries such as India and China are taking their rightful position amongst other nations.

The second wave was also characterised by excessive centralisation, a phenomenon particularly visible in the civil service. In the name of automation and economies of scale, there was one centralised Post Office, one centralised Railway Company, one centralised provider of electricity, etcetera. ${ }^{9}$ Instead of economies of scale, the public was confronted with the inefficiencies of a 'civil' service which was anything but, because no competition was built into the system.

The third wave, which is also known as the information age, has changed all of that dramatically. The asset now considered to be most worthwhile is data, information, knowledge; and the interplay between, and even the basic meaning of, these concepts have had different interpretations. One of the present author's favourite taxonomies comes from Tony Twine, as quoted in a previous edition of one of my works. ${ }^{10}$ At a conference entitled "Knowledge Management - overcoming the information overload", ${ }^{11}$ Twine arranged the above concepts in an ascending order of 'data', 'information', 'knowledge' and 'wisdom'. In the fifth place, the concept of 'intelligence' operates as a catalyst for the other four, transforming, say, data to information, information to

8 The present author recalls how a survey (by show of hands) in high school during the 1960 s revealed that $80 \%$ of our parents had grown up on a farm, whereas we were all being schooled in an urban environment in the rapidly industrialising city of Port Elizabeth.

9 South Africa may rue the over-centralisation of the provision of electricity with 'brown-outs' and 'black-outs' caused, at least partly, by ESCOM (Electricity Supply Commission) having no competition in the market place. Previous President Mbeki has apologised to the citizens of South Africa for this.

10 Van der Merwe Computers and the Law (1986) xviii.

11 Held at Kyalami, Gauteng on 5 August 1998. 
knowledge and knowledge to wisdom. He then argues that among the four assets $^{12}$ we have been discussing so far, namely land, capital, labour and entrepreneurship, only the last-mentioned asset possesses the intelligence to 'process' the other factors.

Again in the work quoted above, ${ }^{13}$ I defined 'data' in an objective sense, in the sense that it lies out there, waiting (like gold ore) for anyone to discover it. 'Knowledge' seems characterised by having become part of a specific person's range of information (often gained by means of experience), whereas 'information' seemed to be a specific person's range of knowledge, but with an element of marketability (transforming it into a commodity) built into it.

'Wisdom', interestingly enough, is defined by an authoritative source ${ }^{14}$ as:

(possession of) experience and knowledge together with the power of applying them critically or practically, sagacity, prudence, common sense.

It is interesting to note the emphasis in the latter term on practical application and common sense. ${ }^{15}$ This reminds one of the quote from Kahlil Gibran: "A little knowledge that acts is worth infinitely more than much knowledge that is idle."16

Finally, the Concise Oxford Dictionary defines 'intelligence' as "intellect, understanding, quickness of understanding, sagacity, information (especially of military value)". This seems to imply evaluation, which is a good thing according to another well-known source, ${ }^{17}$ which finds evaluation to be one of the highest-rated skills and mere understanding to be one of the lowest.

12 Really production resources.

13 See Van der Merwe, supra n 10.

14 Sykes (ed) Concise Oxford Dictionary 1983.

15 Which makes one wonder whether academics may be described as having 'wisdom'.

16 As cited by Van der Merwe, supra $\mathrm{n}$ 10, xix.

17 Bloom Taxonomy for Teaching. 


\section{$3 \quad$ Have other (non-legal) fields kept up with developments in Information Technology?}

Whereas Information Technology is probably one of the fastest-moving fields of human endeavour around, other more traditional areas (such as the law!) have gained reputation for being fairly slow-moving and conservative, often deservedly so. Partly because of this gap, the Industrial Revolution had to spawn the (then brand-new) field of Intellectual Property, which will be explored under the next heading to see if it, perhaps, can also present a solution to the Information Revolution. Unfortunately the law is not alone in this respect (a slow reaction time and a lack of clarity in nomenclature being two of its main characteristics) and a number of other disciplines which promise to look after one's investment in information have also been having problems.

As explained above, an interesting shift in emphasis has occurred between the last two major developments, namely from the Industrial to the Information 'revolutions'. More and more companies are appointing 'ClOs'. ${ }^{18}$ Terms such as 'databases', 'data exchange' and 'data protection' are vying for attention with terms such 'knowledge bases', 'knowledge engineering' and 'knowledge management'.

Each of these terms has developed an own field of expertise surrounding it, with a highly sophisticated group of professionals making a very good living out of mining this new ore. In addition, some very old professions have gained a new lease of life, such as that of the archivist. $^{19}$ The present article will concentrate on the last-mentioned profession of archivist, because these people (whether we call them 'database managers' or 'knowledge engineers') seem to be the "keepers of the keys" to the gold of the twenty-first century.

18 Chief Information Officers.

19 The oldest profession of all, rather less respectable than that of the archivists, has also adapted quite well to the IT world, but perhaps the less said about that, the better! 
One of the foremost archivists, Lester J Cappon, was of the opinion that an archivist was "somewhere between the librarian and the historian". ${ }^{20}$ He saw prior stages of the "the still-emergent discipline" as much less developed than even at the stage of his writing that particular article (in 1940). ${ }^{21}$ One wonders what Cappon would have said of the twenty first century's 'computer archiving'?!

Looking at the etymological roots of the terms Cappon was discussing, it is clear that the word 'librarian' is, in fact, quite dated. It is derived from the word liber, which means 'book' in Latin. ${ }^{22}$ This is almost as dated as 'manuscript', which is derived from the Latin scriptare, meaning 'to write' and manu, meaning 'by hand', thus pre-dating even the industrial revolution! ${ }^{23}$ The word 'historian' comes from the Greek root histor which means 'learning' and therefore represented a 'wise man'. ${ }^{24}$

The etymological roots of 'archive' and 'archivist' are slightly less clear. The definition of 'archive', according to the Concise Oxford Dictionary, ${ }^{25}$ is a "place in which collected public or corporate records are stored". This term is etymologically derived from the Greek words arkheia meaning 'public records' and arkhe, meaning 'government'. ${ }^{26}$ When one scans the list of English words with the antecedent 'arch-', however, it seems that most of these prefixes may be translated as 'chief' or 'head', which would fit in with the above definition's focus of 'public' or 'government' records. Examples of these include 'archangel', 'archbishop', 'archduke', 'arch-enemy' and 'arch fiend'. ${ }^{27}$ Interesting, but probably quite coincidental, is how many of these government positions have religious connotations!

Cox Golden Age of Archival Theory 8.

Ibid.

Sykes (ed) Concise Oxford Dictionary 579.

Ibid, 617.

Ibid, 473. Nowadays this would doubtless include a 'wise woman' too, although in medieval times she had to run the risk of being burnt at the stake as a witch! Present-day nomenclature should therefore rather use the term of a 'wise person'.

Sykes (ed) Concise Oxford Dictionary 45.

Ibid.

Ibid. 
On the other hand, one also finds an equally impressive list of words with the antecedents 'archa' or 'archae-', where the relevant prefixes may be translated as 'ancient' or 'pre-historical'. ${ }^{28}$ Examples of these include 'archaeology', 'archaic' and 'archaeopterix' (the last meaning "the oldest known fossil bird, with a tail like a reptile's")!

This etymological debate is not quite as tangential to the main theme of this article as it might prima facie appear to be. According to archival science, as well as according to the Oxford Dictionary definition, archivists should confine themselves to public or corporate records and should leave 'private papers' to the 'historians'. To my mind, such a limiting definition simply means that archival science is denying itself the important role it was surely destined to play in the brave new world of Information and Communications Technology (ICT). This is acknowledged in the work on Lester Cappon quoted above, ${ }^{29}$ where the fact is bemoaned that personal manuscripts have been ignored by archivists "missing the fact that archives encompass personal papers".

More germane to the central theme of the present article is what the effect of modern technology, with its emphasis on ICT, is likely to have on archives and archival science. Cappon was still of the 'old school' in this respect and "began to argue with archivists who thought that the new technologies were transforming basic principles" (of archival science). ${ }^{30}$ A sympathetic commentator feels that this might simply be because Cappon had been upon the scene for too long when the computer made its entrance:

Had the issue of machine-readable or electronic records emerged in full force a decade or two earlier, I think we would have seen Cappon delve into the history of recordkeeping as he had genealogical research or documentary editing or the administration of presidential libraries. ${ }^{31}$ 
Still, one wonders what Cappon (or even more 'modern' archivists) would make of the following definition of the ICT version of an 'archive':

1. An infrequently accessed but comprehensive collection of data.

2. A file designed for space-efficient storage or distribution that contains two or more original files. In Unix the most popular archive program is tar, which lacks compression capabilities. In Microsoft Windows, WinZip is the most popular archiving and compression program, while Stuff It holds this place among Macintosh users. ${ }^{32}$

The first part of the definition obviously tries to convey that it refers to data which has been placed "in a cupboard" for a considerable period of time, for possible use later on. It seems to imply a longer period of time than ordinary ICT 'storage', which happens every few minutes automatically when one is busy working on an ordinary word-processing program, for instance. ${ }^{33}$

The second part of the definition incorporates the technical process of 'compression', for which there is really no equivalent in the older world of paper documents. The data undergoes a conversion which dramatically decreases the size of the file concerned, and each of the three main computer operating systems has its own version of a compression program. It is therefore a form of 'deep storage' which needs a (computer-based) technical process to unlock the data for further use.

For purposes of the Law of Evidence it is interesting to note that the compression process also enables the receiving machine to detect whether the data message has undergone any changes en route. It does so by keeping count of all the bits and bytes which have been compressed into a 'hash total' before going on its inter-computer journey, and counting these again when they arrive on the other side. The digital effects of computers on information which

32 Pfaffenberger (ed) Webster's Dictionary of Computer Terms 34-35.

33 At first the fact that the definition of a 'data message' (in s 1 of the Electronic Communications and Transactions Act 25 of 2002, hereafter 'ECT Act') included stored data bothered the present author, because of the connotation of a 'message' as something that travels or moves. However, the greater permanence of archived data would have made the situation even worse. 
has to be brought before court as evidence have been adequately explored by the present author in other articles and the reader is referred to those sources for further reference. ${ }^{34}$ Perhaps one of the main points to keep in mind is the distinction between the 'Paper' and the 'Protocol' approaches. The former tries to approximate the record-keeping and security functions of paper as closely as possible, going so far as to try to replicate the traditional best-evidence rule by creating an artificial 'original' from one of the many print-outs. The 'Protocol' approach gets away from paper, 'hard copies' and 'wet signatures' entirely and places its trust in an adherence to standards and best practice, especially those adopted by those engaged "in the ordinary course of business".

In conclusion though, it would seem that data - knowledge - or information science is going to struggle to protect data (whether 'raw' or in one of its more refined forms) adequately without the normative and coercive support of the courts and the lawyers. ${ }^{35}$ It is this topic which will be explored under the next heading. In order to keep from having to make the quadruple distinction between all of these abovementioned forms, the present article will simply use the term 'knowledge', even though it might not be quite correct in the technical sense.

\section{$4 \quad$ Has the Law kept up with developments in Information Technology?}

\subsection{The Law of Intellectual Property}

The Law of Intellectual Property ('IP law') has unfortunately not coped as well with the Information Era as it has with the Industrial Era. The Law of Patent used to work quite well by giving companies a limited ${ }^{36}$ legal monopoly on

34 See for instance Van der Merwe 2005 Obiter 665ff and 2005 JCRDL 69.

35 Especially given that ethical and moral restraints seem even lower when data is at stake.

36 Twenty years ito the Patents Act 57 of 1977. 
hardware ${ }^{37}$ and 'firmware' ${ }^{38}$ in return for an expensive and quite lengthy registration process.

It is interesting to note that a computer programme (or software) has been specifically excluded from patentability. ${ }^{39}$ Nevertheless, the software giant Microsoft now prides itself on the thousands of programmes which it patents on an annual basis. The fact that these programmes are probably not patentable in British-based systems (such as those obtaining in South Africa) does not seem to bother the firm over-much. ${ }^{40}$

Nonetheless, the question still remains: Can one register a patent on information? A practical illustration, showing that this is not merely an academic debate, is the struggle continuing around the promising data structure XML. ${ }^{41}$ । have explored the benefits of XML in another article, ${ }^{42}$ but suffice it to say that it enables users to extract much better value out of their databases. It may be compared to the metal smelter/purifier extracting the refined product from the ore which has been mined. The fact that Microsoft has spent so much time and effort in trying to patent its own 'flavour' of XML, called OOXML, ${ }^{43}$ shows that the company has firmly placed its trust in patent to protect one of its most precious assets, namely information, as well as into one of the most valuable tools for imposing structure onto information.

The matter is finally settled neither in the United Kingdom nor in South Africa. In the former country, the government is appealing a High Court court ruling that granted the company Symbian a right of patent in certain 'firmware' which drives the Dynamic Link Library (DLL) in many operating systems. ${ }^{44}$ The South

37 The computing machinery, or 'box' itself.

38 Basically a piece of hardware fulfilling the same function as software normally does (for instance, being programmable).

39 Patent Act 57 of 1978 subs 25(2).

40 It would probably rely on a 'contract' created by the users having clicked on a button entitled 'I agree' before starting the programme.

41 'eXtensible Markup Language'.

42 Van der Merwe 2005 Obiter $665 \mathrm{ff}$.

43 'Open Office XML'. This is in opposition to the open source program ODF ('Open Document Format').

44 Anon 2008 BBCNews http://news.bbc.co.uk/ 21 Mar. 
African Minister of Public Service and Administration, Geraldine FraserMoloketi, at a recent inter-Africa conference (in Senegal) criticised the firm Microsoft for pushing its own (expensive) software instead of adopting the (free) Open Document Format. ${ }^{45}$

Thus an idea, by itself, is firmly excluded from patentability by the South African Patent Act. ${ }^{46}$ Nonetheless, the fact that a patentable 'contraption' still has to be adequately described and the description itself lodged with the Patent Office before a patent may be granted means that supplying information ${ }^{47}$ is an important step towards obtaining a valid patent.

Copyright law has, almost as an afterthought, also decided to protect information. After an amendment by the Copyright Amendment Act, ${ }^{48}$ the South African Copyright $A c t^{49}$ has now been specifically changed in this regard. Section One has always listed a 'literary work' as one of the categories of works which may be protected by copyright. The Amendment Act has now extended the definition so as to also include 'tables and compilations' under literary works.

There is no doubt that 'tables and compilations' would probably include certain structured information, but the question remains exactly how far the definition goes in this regard. In her work Recordkeeping Ethics and the Law ${ }^{50}$ Livia lacovino expresses optimism as to the capabilities of copyright to protect information:

Intangible personal property, protected through intellectual property (law), in particular copyright, patents and trademarks, has been the major developmental areas in Internet regulation. Copyright, in particular, because of its obvious connection to the content on the Internet, may provide a preferable legal means of ownership of

45 Anon 2008 http://www.tectonic.co.za 19 Mar.

46 Act 57 of 1978 s 46(1).

47 In the form of the description.

48 Act 125 of 1992.

49 Act 98 of 1978.

50 lacovino Recordkeeping, Ethics and the Law 233-234. 
electronic records rather than concepts of personal property already discussed.

Personally, I would rather go along with the opinion of John Perry Barlow ${ }^{51}$ (as quoted in Lawrence Lessig's Code), ${ }^{52}$ who is rather more pessimistic about the potential of the Law of Intellectual Property to protect information:

(C)opyright and patent law was designed to convey forms and methods of expression entirely different from the vaporous cargo it is now being asked to carry.

Does the criminal law hold out any better hope for adequate legal protections of 'the vaporous cargo' represented by information? This will be discussed under the next heading.

\subsection{Criminal Law}

Before one gets to information crime, one should perhaps look at information security because "an ounce of prevention is worth a pound of cure". ${ }^{53}$ The area of information security is also one that is well-developed but space will not allow us to explore this field adequately in the present article. Suffice it to say that encryption is probably one of the most effective ways to prevent unauthorised persons from getting access to sensitive information.

As was said above, encryption is also one way of making sure that information comes before court in the form of uncorrupted evidence. The ways in which information helps the law to 'do its job' may be termed 'legal informatics', in contrast to 'informatics law', where the law has to try and help information scientists solve their troubles. ${ }^{54}$ In this regard, an important part of legal informatics consists of 'forensics' which really means "science in the service of the court". 55

51 Barlow 1994 Wired 85.

52 Lessig Code 264, n 14.

53 According to imperial measure there were 16 ounces to one pound of weight

54 See in this regard the present author's Computers and the Law (2000) $265 \mathrm{ff}$.

55 The Latin words forum and forensics mean 'court'. 
Can one steal information? Using the computer as a tool in order to steal money ${ }^{56}$ is, of course, not quite the same thing. To give a brief answer to this question, the British decision of Oxford $v$ Moss ${ }^{57}$ decided that a student looking at an examination paper cannot be charged with theft, because the information contained in the paper was not 'corporeal' enough.

In one of the earliest works on computer crime in South Africa (entitled, quite aptly, Computer Crime in South Africa) ${ }^{58}$ the authors split computer crime up into several categories. One of these types is entitled 'Theft of information'.

In a prior work, Computers and the $L a w,{ }^{59}$ the present author's reaction to the outcome of the cases cited in this work was not very flattering:

The second category, theft of information, did not lead to any legal sanction in any of the cases discussed. The worst thing that happened to any of the perpetrators was a reprimand! Most of the cases involved unauthorised users looking at information or authorised users later on making use of information in unauthorised ways. All these cases seem to me to illustrate that information is an exceedingly valuable asset and that it would be a defect in the criminal law to deny dogmatically the possibility of the theft of information or even to try to and force all such cases in to the mould of trade secrets. ${ }^{60}$

This stands in very sharp contrast to any type of information which might be of use to the military. It is popularly assumed that "spies might be shot". Reference has been made above ${ }^{61}$ to the concept of 'intelligence', which would seem to highest up in the various forms of information, because it supplies the logical and conceptual infrastructure to help make sense of the incoming streaming of data by evaluating such data:

56 Even though the 'money' might be in a digitised form.

57 (1978) $68 \mathrm{Cr}$ App R 183.

58 Credo and Michels Computer Crime in South Africa.

59 Van der Merwe Computers and the Law (2000) 192.

60 Ibid, 192.

61 See par 2 above. 
Finally, the Concise Oxford Dictionary defines 'intelligence' as "intellect, understanding, quickness of understanding, sagacity, information (especially of military value)".

In South Africa the Constitution ${ }^{62}$ imposes the duty on the president to establish an intelligence service and appoint a Minister to exercise oversight over this body. The country's national Legislature should also enact specific legislation to regulate the objects, powers and functions of the Intelligence Services. ${ }^{63}$ This has been done and the National Strategic Intelligence Act (NIA) ${ }^{64}$ has ever since looked after the protection of 'military' or 'national' intelligence. It is instructive to look at some of the definitions of the Act in this regard:

"crime intelligence" means intelligence used in the prevention of crime or to conduct criminal investigations and to prepare evidence for the purpose of law enforcement and the prosecution of offenders;

"departmental intelligence" means intelligence about any threat or potential threat to the national security and stability of the Republic which falls within the functions of a department of State, and includes intelligence needed by such department in order to neutralise such a threat;

"domestic intelligence" means intelligence on any internal activity, factor or development which is detrimental to the national stability of the Republic, as well as threats or potential threats to the constitutional order of the Republic and the safety and the well-being of its people;

"domestic military intelligence" means intelligence required for the planning and conduct of military operations within the Republic to ensure security and stability for its people.

From the above four definitions it is clear that the first two should do excellently well to combat ordinary crime, of the type with which South Africa seems presently to be over-burdened with. The relevant 'department' spoken of could be the Department of Justice, the Police, Prisons et cetera. 
The last two would seem to fit in better with one's conventional idea of espionage and counter-espionage in the form of 'intelligence-gathering'. The same would go for the corresponding concepts of 'foreign intelligence':

"foreign intelligence" means intelligence on any external threat or potential threat to the national interests of the Republic and its people, and intelligence regarding opportunities relevant to the protection and promotion of such national interests irrespective of whether or not it can be used in the formulation of the foreign policy of the Republic

and (especially) "foreign military intelligence":

"foreign military intelligence" means intelligence regarding the war potential and military establishment of foreign countries (including their capabilities, intentions, strategies and tactics) which can be used by the Republic in the planning of its military forces in time of peace and for the conduct of military operations in time of war.

It is a pity that the Act has not given us a pure definition of intelligence by itself, given the tremendous importance which all these definitions obviously attach to the concept of 'intelligence'. In the end, one would probably not be too far off from the Concise Oxford Dictionary definition ${ }^{65}$ of "information (especially of military value)".

Besides the protection and gathering of intelligence, the South African Parliament has also tried to arrange for the same to be done with regard to 'information', by means of a Protection of Information Act. ${ }^{66}$ In the latest development on this front, ${ }^{67}$ the Minister for Intelligence Services has made a new Bill in this regard available for comment. The Bill proposes creating a number of new offences (including the crime of espionage), provides for the classification, declassification and 'downgrading' of information ${ }^{68}$ and interestingly, provides a very wide definition of information itself:

65 Cited above.

66 Act 84 of 1982.

67 This is at the time of writing, which is the $1^{\text {st }}$ of April 2008 (no joke!).

$68 \mathrm{~S} 1$ of the Bill. 


\section{Nature of information}

4. 'Information,' for the purposes of this Act includes any facts, particulars or details of any kind, whether true or false, and contained in any form, whether material or not, including, but not limited to:

(a) Documents, records, data, communications and the like whether in paper, electronic, digital, audio-visual format, DVD, microform C, microfilm and microfiche form or format or any other form or format; and

(b) conversations, opinions, intellectual knowledge, voice communications and the like not contained in material or physical form or format.

In the opinion of the present author it seems strange to classify documents, records and communications next to data, whereas the foregoing really all consist of manifestations of data, especially when in digital format.

The protection of information by means of the Criminal Law has spawned some interesting doctoral research in South Africa. One of the first of these was Die Regsbeskerming van Inligting ${ }^{69}$ by Tertius Geldenhuys. He makes the point that it is not so much information itself which is being protected, but individual and community interests with regard to information. These interests may be divided up into private and public law interests. With regard to the private law interests, many categories of information already enjoy protection as the objects of subjective rights. With regard to the public law interests in information, after an exhaustive research Geldenhuys finds that the interests of the executive are perhaps over-protected, particularly as far as state secrets are concerned.

In contrast, Catharina Nienaber's Strafregtelike Beskerming van Inligting ${ }^{70}$ concentrates a bit more on private law interests, particularly as far as industrial espionage is concerned. Given the uncertainty of the protection of common-law proprietary rights in information, she creates a new concept: "beskermings-

69 The Legal Protection of Information (translation). See Geldenhuys Regsbeskerming van Inligting.

70 The Protection of Information by means of Criminal Law (translation). See Nienaber Strafregtelike Beskerming van Inligting. 
waardige inligting". The adjective is impossible to translate with one word, and one would probably have to come up with a phrase such as 'information which is worthy of protection'. Of interest, too, is her introduction of concepts such as 'ideas' and 'wisdom', which she discusses together with the concepts that the reader has been confronted with so far.

In summation, on the public law side information seems to be given its proper protection, especially when any kind of war-like, espionage situation is involved. The same cannot be said of the private law, however. There is no doubt that a great amount of industrial espionage takes place, yet it seems that the criminal law is not overly concerned with, or perhaps capable of, protecting the victims in this instance.

\subsection{Private Law}

After the work entitled $1984,{ }^{71}$ the prospect of one's personal privacy being invaded by an 'all-seeing eye' is probably everyone's favourite nightmare. However, using a modern version of the law of contract in order to accomplish 'e-commerce' is as much part of modern private law as is taking one's refuge in the law of privacy. One would, for instance, sometimes have to give up some information 'voluntarily' in order to take part in e-commerce, thus suffering the lesser of the two evils.

Because of South African private law's unique development in this regard, ${ }^{72}$ it would not serve much purpose to look comparatively at the "Law of Obligations" of countries such as the United Kingdom, Canada, Australia and New Zealand.

Looking at the concept of the protection of personal privacy first, what has developed into a very well-profiled area of law in these (and many other)

71 A book written in 1948 by George Orwell (also author of the futuristic Animal Farm). To express the future in the title of the first book he simply swopped around the final two digits of the year he was writing in.

72 Being an uncodified civil law system, based on Roman law as it was developed by the Dutch before that country's system was codified. 
countries is the protection of individual privacy by means of protecting personal data, under the title of 'data protection'.

Annaliese Roos describes the contents of this last concept as follows:

Data protection ${ }^{73}$ can be defined as a set of measures aimed at safeguarding individuals (or persons) (called data subjects) from harm resulting from the computerised or manual processing of their personal information by data controllers. These measures embody a group of principles on the processing of personal information.

According to Roos, ${ }^{74}$ the concept of 'personal data' can be defined as:

any information relating to an identified or identifiable person. An identifiable person is one who can be identified directly or indirectly by reference to an identification number or to one or more other factors that are specific to the person's physical, physiological, mental, economic, cultural or social identity.

Even though the South African Constitution ${ }^{75}$ guarantees each citizen the right to privacy, legislation along the lines recommended has been a long time in coming. The South African Law Reform Committee (SALRC) has brought out a concept proposal in this regard in the form of a draft Bill and legislation along those lines will probably be enacted in the near future. The product of the SALRC is entitled Privacy and data protection ${ }^{76}$ and shows evidence of careful research. It is to be hoped that the legislation will not bedelayed any further, for whatever reasons.

The ECT Act contains a number of sections in this regard, ${ }^{77}$ but these are not binding on participants in the process of electronic commerce. One may very well ask what benefit then accrues to such 'voluntary' participants. The answer

73 From a soon-to-be published work entitled ICT Law together with co-authors Eiselen, Pistorius and Van der Merwe. According to Roos the term originates from the German term 'Datenschutz', although many countries, such as the USA, prefer to use the term data or information privacy, rather than data protection.

74 Ibid.

75 Constitution of the Republic of South Africa,1996.

76 SALRC Privacy and Data Protection Discussion Paper 109 http://www.doj.gov.za/salrc/ 21 Mar.

77 Act 25 of 2002, s $50 f f$. 
probably lies in the fact that one would be able to affix some sort of 'seal of approval' to one's website (or any other form of advertising) saying or boasting to the effect: "voluntarily compliant with the privacy provisions of the Electronic Communications and Transactions Act"!

Long before the ECT Act came along, the present author presented his own solution as to how the criminal law could integrate the protection of information. In an article entitled "Diefstal van Onliggaamlike Sake met Spesifieke Verwysing na Rekenaars", ${ }^{78}$ two (and a half) solutions were offered. One would be for the Law of Things (as part of Private Law) to extend its field of application so as to also include intangibles. ${ }^{79}$ Another would be for the Criminal Law to extend the category of things which may be stolen. ${ }^{80}$ The half a solution (not recommended) would be for concepts such as 'ownership', 'possession' and 'thing' to have varying content, depending on which field of law is involved.

Dealing with the electronic commerce side, I cannot do better than to borrow the following quotation from my colleague and co-author, ${ }^{81}$ Sieg Eiselen, which he took from President Clinton of the United States: ${ }^{82}$

The invention of the steam engine two centuries ago and the subsequent harnessing of electricity for communications ushered in an industrial revolution that fundamentally altered the way we work, brought the world's people closer together in time and space, changed the way we organize our economies, and brought us greater prosperity.

Today, we are on the verge of another revolution. Inventions like the integrated circuit, the computer, fibre optic cable, and the Internet are changing the way we work, learn, and communicate with each other.

78 The theft of intangibles with specific reference to computers (translation). See Van der Merwe 1985 SACC 129ff.

79 Because intangible could now be 'owned', it would also be possible to 'steal' them.

80 Unfortunately an important link between the Criminal and Private Law would then be lost.

81 See supra $\mathrm{n} 73$.

82 Clinton 1997 http://www.technology.gov/ 26 Aug. 
As the Internet empowers citizens and democratizes societies, it is also changing the way business is conducted: entrepreneurs are able to start new businesses more easily by accessing the Internet's worldwide network of customers; world trade involving computer software, entertainment products, information services, professional consulting, financial services, education businesses, medical diagnostics, advertising, and technical services is increasing rapidly as the Internet dramatically lowers costs and facilitates new types of commercial transactions; engineers, product developers, and managers thousands of miles apart can collaborate to design and manufacture new products more efficiently; businesses can work more efficiently with their suppliers and customers; consumers have greater choice and can shop in their homes for a wide variety of products from manufacturers and retailers all over the world, and they will be able to view these products on their computers or televisions, access information about the products, and order and pay for their choices, all from their living rooms.

According to Eiselen, Chapter III of the ECT Act ${ }^{83}$ has now firmly taken South Africa into the e-commerce era. He notes that many people had expected 'Electronic Data Interchange' (EDI) to be huge success, but that this technology has been almost entirely replaced by people contracting directly with each other by means of the Internet. EDI was a form of regular 'business-to-business' $(\mathrm{B} 2 \mathrm{~B})^{84}$ electronic contact with fixed trading partners, whereas the Internet, of course, enables 'business-to-customer' (B2C) electronic contact, on a twentyfour-hours-a-day basis, if necessary. In this regard, Amazon.com is probably the example that springs to mind almost immediately, in that it sells its books (and related products) to the world by means of the Internet.

As with Criminal Law, Private Law seems to be having mixed success in South Africa. Privacy is still not protected and the Law of Things is uncertain, whereas electronic contracting is taking place every minute and being governed by the provisions of the ECT Act. With the latter one has to keep in mind, however, that the Internet is simply an instrument by means of which (ordinary) goods are bought and sold. 
As soon as one starts dealing with information itself as the object of the electronic transactions on the Internet, the situation becomes slightly more complicated. The success stories in this regard, namely sites such as 'Google' 85 and the 'Wikipedia', ${ }^{86}$ do not charge for their services at all.

The final question to be answered as far as e-commerce in the form of trading in information is concerned is how sites such as Google "make a living". The answer probably lies in the number of visitors which such Internet sites attract daily. ${ }^{87}$ The fact that there are so many "feet on the beat" means that advertising on such a site becomes a prized commodity - so prized, in fact, that it probably pays the running costs of the site itself as well as handsome profit for the founders and proprietors. In addition, the site owners gather valuable information concerning their electronic visitors, which information may be further sold.

\subsection{Legal philosophy}

In a field as complicated as the present one, it often helps to go back to the fundamental principles of law in order to find guiding principles of law which would help to answer difficult legal questions. To mention but one question that the present author would like an answer to: is technical convergence going to lead to legal convergence?

I have spent some time discussing this very question in a previous work ${ }^{88}$ and remarked there that "the physical form of technology employed is no longer as important as the use to which the technology is being put". A good example of this is the new South African Electronic Communications Act, ${ }^{89}$ which was formerly (perhaps more aptly) entitled the 'Convergence Bill'. This combined the fields of telecommunications, information technology and broadcasting.

85 At http://www.google.com.

86 At http://www. wikipedia.com.

87 And 'nightly', since they are open for 'business' 24 hours per day!

88 Van der Merwe, supra n 59, xiii ff.

89 Act 36 of 2005. 
Another good example of this 'convergence' is how the (legally) distinct categories of goods, which were severally protected by copyright, have now merged into 'multimedia' products, which cannot be situated easily in any one category. An example here would be the multimedia encyclopaedia 'Encarta', ${ }^{90}$ which contains audio, video, music and a lot of text. It is time for copyright lawyers to show some vision and start thinking "out of the box".

In her work Recordkeeping, Ethics and the Law, Livia lacovino does a manful (sic) job of marrying the law and record-keeping to the online world. She contrasts three different models in this regard, namely the postmodernist, the historical-analytical and the practice skills models. ${ }^{91}$ lacovino seems to favour the postmodernist stance. This may be described as a reaction against the Kantian classification of everything into absolute categories, as a rediscovery of values and as the realisation that every legal subject might be a "law unto themselves". Even though she admits that "postmodernism has not had much direct impact on legal thinking and practice" ${ }^{92}$ there is hope that the influence which this system of philosophy has had on European thinking might lead to a convergence in approach by legal systems, including those having to deal with information matters. This view is supported by Reinhard Zimmermann in his work The Law of Obligations: Roman Foundations of the Civilian Tradition. ${ }^{93} \mathrm{He}$ makes it clear that in the Law of Obligations, particularly at the structural level, the differences between common and civil law systems are not that great.

On the public law side, governance in the world of the Internet is also an interesting matter, because this would determine who the law-giver should be. lacovino describes ${ }^{94}$ the two opposing standards, namely that of Marshall McLuhan with his vision of a 'global village', as opposed to Ingrid Volkmer, who foresaw parallel communities, each concentrating on its own interests. The latter model seems to be winning because it has become very difficult, if not

90 This is the Microsoft product - the electronic version of Encyclopaedia Britannica is a rival.

91 lacovino, supra $\mathrm{n} 50,4$.

92 Ibid, 9.

93 As cited by lacovino, supra n 50, 10.

94 lacovino, supra n 50, 214. 
impossible, for a government to control its own citizens when they are wandering around in cyberspace: ${ }^{95}$

Governments, for example Singapore, have been unsuccessful at control over the content distributed over the Internet, due to regulatory arbitrage, which allows moving an activity to a jurisdiction which is favourable to non-control.

Another victory for the postmodernists, it would seem therefore!

\section{$5 \quad$ Conclusion}

If the present author had to choose between the two absolute models presented under the previous heading, one would probably have to come down on the side of postmodernist stance. There might be a middle way, however, which would also fundamentally affect the way in which one views the relationship between law and information.

This article started with a reference to the English author and philosopher, Sir Francis Bacon. Bacon seems to be placed firmly on the 'scientific' side of the above debate. He would seem to be more of an empiricist, however, arguing by induction from specific (observations) to general (conclusions), than a theorist, arguing by deduction from general (theorems) to specific conclusions. Bacon has been called "the great genius behind the scientific revolution" and historians of the philosophy of science have seen in him the beginning of inductive reasoning. ${ }^{96}$

Even though "(t)oday's historians of science try to present Bacon as a thorough-going materialist" 97 the modern author Black paints another picture in

95 Ibid, 216.

96 Black Secret History of the World 334.

97 Ibid. 
that "Bacon also believed in the same ethereal intermediary between spirit and matter as Newton". ${ }^{98}$

Could this intermediary, acting as a medium between the intangible and the tangible, be information itself? Could this be the 'vaporous cargo' referred to above ${ }^{99}$

According to Marshall McLuhan's work Understanding Media, ${ }^{100}$ specifically in the essay entitled "The Medium is the Massage", ${ }^{101}$ this might very well be the case. Only when a society or an industry starts dealing with information intensively does it become an 'information society' or an 'information industry':

Indeed, it is only too typical that the "content" of any medium blinds us to the character of the medium. It is only today that industries have become aware of the various kinds of business in which they are engaged. When IBM $^{102}$ discovered that it was not in the business of making office equipment of business machines, but that it was in the business of processing information, then it began to navigate with clear vision.

What McLuhan seems to be trying to say is that what one is exercising one's wits on might very well influence those very wits themselves in the course of time. In other words, by working with information one becomes 'attuned to' such information and therefore equipped for working with the Information Society. Whether one calls this educated entity 'mind', 'intellect' or 'spirit' does not really matter - it comes down to a deep understanding.

Hopefully lawyers will lift their heads from their legal practices long enough to do some thinking ${ }^{103}$ about the age in which they find themselves and will also be able to deal with informatics law (as well as with legal informatics) "with clear vision".

98 Ibid.

99 See the end of par 4.1 above.

100 McLuhan Understanding Media.

$101 \mathrm{lbid}, 15 \mathrm{ff}$.

102 An acronym for 'International Business Machines'.

103 It is said that a former chairman of IBM had a single plaque affixed to the wall of each employee's office, reading simply 'THINK!'. 


\section{Bibliography}

Barlow 1994 Wired

Barlow JP "The Economy of Ideas: A Framework for Rethinking Patents and Copyrights in the Digital Age" 1994 Wired magazine 85

Black Secret History of the World

Black J The Secret History of the World As laid down by the Secret

Societies (Quercus London 2007)

Bloom Taxonomy for Teaching

Bloom BS Taxonomy for Teaching, Learning and Assessing (A); a Revision

of Bloom's Taxonomy of Educational Objectives (Longman New York 2001)

Cox Golden Age of Archival Theory

Cox RJ Lester J. Cappon and the Relationship of History, Archives and Scholarship in the Golden Age of Archival Theory (Society of American Archivists Chicago 2004)

Credo and Michels Computer Crime in South Africa

Credo P and Michels J-P Computer Crime in South Africa (Data Time Johannesburg 1986)

Geldenhuys Regsbeskerming van Inligting

Geldenhuys T Die Regsbeskerming van Inligting (1993 LLD UNISA)

lacovino Recordkeeping, Ethics and the Law

lacovino L Recordkeeping, Ethics and the Law: Regulatory Models,

Participant Relationships and Rights and Responsibilities in the Online World (Springer Dordrecht 2006)

Joubert and Faris (eds) LAWSA

Joubert WA and Faris JA (eds) The Law of South Africa (Butterworths

Durban 2000) feris of faris? 


\section{Lessig Code}

Lessig LJ Code and other laws of Cyberspace (Basic Books New York 1999)

McLuhan Understanding Media

McLuhan M Understanding Media, the extensions of man (McGraw-Hill New York 1964)

Nienaber Strafregtelike Beskerming van Inligting

Nienaber C Die Strafregtelike Beskerming van Inligting (2005 LLD UNISA)

Orwell 1984

Orwell G 1984: A Novel (Signet Classic New York 1948)

Pfaffenberger (ed) Webster's Dictionary of Computer Terms

Pfaffenberger B (ed) Webster's New World Dictionary of Computer Terms $8^{\text {th }}$ ed (Que New York 2000)

Sykes (ed) Concise Oxford Dictionary 2001

Sykes JB (ed) Concise Oxford Dictionary $7^{\text {th }}$ ed (Clarendon Press Oxford 2001)

Sykes (ed) Concise Oxford Dictionary 1983

Sykes JB (ed) Concise Oxford Dictionary of current English (Clarendon Press Oxford 1983)

Toffler The Third Wave

Toffler A The Third Wave (Morrow New York 1980)

Van der Merwe 2005 Obiter

Van der Merwe DP "How Standards (such as XML) Accomplish Electronic Authentiocation in Web Services" 2005 Obiter 665-686

Van der Merwe 2005 JCRDL

Van der Merwe DP "XML and the Law - where the Former is Taking the Latter" 2005 Journal for Contemporary Roman Dutch Law 69 
Van der Merwe 1998 SALJ

Van der Merwe DP "Copyright and Computers, with special reference to the Internet" 1998 SALJ 180-196

Van der Merwe 1985 SACC

Van der Merwe DP "Diefstal van Onliggaamlike Sake met Spesifieke Verwysing na Rekenaars" 1985 (2) SACC 129-141

Van der Merwe Computers and the Law (2000)

Van der Merwe DP Computers and the Law $2^{\text {nd }}$ ed (Juta Kenwyn 2000)

Van der Merwe Computers and the Law (1986)

Van der Merwe DP Computers and the Law (Juta Cape Town 1986)

Van der Merwe et al ICT Law

Van der Merwe DP et al Information and Communications Technology Law

(LexisNexis Durban 2008)

Zimmermann Law of Obligations

Zimmermann R The Law of Obligations: Roman Foundations of the Civilian

Tradition (Kluwer The Hague1993)

\section{Register of legislation}

Constition of the Republic of South Africa 1996

Copyright Act 98 of 1978

Copyright Amendment Act 125 of 1992

Electronic Communications Act 36 of 2005

Electronic Communications and Transactions Act 25 of 2002

National Strategic Intelligence Act 39 of 1994

Patent Act 57 of 1977

Protection of Information Act 84 of 1982

\section{Register of court cases}

Oxford v Moss (1978) 68 Cr App R 183 (UK) 


\section{Register of internet sources}

Anon 2008 BBCNews http://news.bbc.co.uk/ 21 Mar

Anonymous 21 March 2008 "Call for clarity on Code Patents" BBCNews

[Found on internet] http://news.bbc.co.uk/go/pr/fr/-/1/hi/technology/7307375

[Date of use 21 March 2008]

Anon 2008 http://www.tectonic.co.za 19 Mar

Anonymous 2008 SA Minister slams software patents [Found on internet]

http://www.tectonic.co.za [Date of use 19 March 2008]

Clinton 1997 http://www.technology.gov/ 26 Aug

Clinton W 1997 Presidential Directive on Electronic Commerce [Found on internet] http://www.technology.gov/digeconomy/presiden.htm [Date of use 26 August 2007]

SALRC Privacy and Data Protection Discussion Paper 109

http://www.doj.gov.za/salrc/ 21 Mar

South African Law Reform Commission Privacy and Data Protection

Project 124 Discussion Paper 109 [Found on internet]

http://www.doj.gov.za/salrc/ [Date of use 21 March 2008]

\section{List of websites}

Google http://www.google.com

Wikipedia http://www.wikipedia.com

\section{List of abbreviations}

$\begin{array}{ll}\text { B2B } & \text { business-to-business } \\ \text { B2C } & \text { business-to-customer } \\ \text { ECT } & \text { Electronic Communications and Transactions Act } \\ \text { EDI } & \text { Electronic Data Interchange } \\ \text { IP } & \text { Intellectual Property } \\ \text { OOXML } & \text { Open Office eXtensible Markup Language } \\ \text { par } & \text { paragraph(s) } \\ \text { S } & \text { section(s) }\end{array}$


SALRC

subs

XML
South African Law Reform Committee subsection(s)

eXtensible Markup Language 